\title{
ANALYSIS OF FAILURES AND RELIABILITY MODEL OF FARM TRACTORS
}

\begin{tabular}{|c|c|}
\hline \multicolumn{2}{|c|}{$\begin{array}{l}\text { a Department of Construction, Exploitation of Vehicles and Machines, University of Warmia } \\
\text { and Mazury in Olsztyn, Poland, e-mail: napj@uwm.edu.pl ORCID 0000-0003-2953-7402 }\end{array}$} \\
\hline \multicolumn{2}{|c|}{$\begin{array}{l}\text { Department of Construction, Exploitation of Vehicles and Machines, University of Warmia and } \\
\text { Mazury in Olsztyn, Poland, e-mail: jaroslaw.gonera@ uwm.edu.pl ORCID 0000-0001-7758-2684 }\end{array}$} \\
\hline \multicolumn{2}{|c|}{ *Corresponding author: e-mail: napj@uwm.edu.pl } \\
\hline ARTICLE INFO & ABSTRACT \\
\hline $\begin{array}{l}\text { Article history: } \\
\text { Received: April } 2020 \\
\text { Received in the revised form: } \\
\text { May } 2020 \\
\text { Accepted: May } 2020\end{array}$ & \multirow{2}{*}{$\begin{array}{l}\text { Farm tractors due to the nature of their work are exposed to a substantial } \\
\text { risk of failures. The issues of their reliability are unusually significant } \\
\text { in the aspect of the time limit of realisation of agricultural works in } \\
\text { agrotechnical seasons. Nowadays, tractors provided for agriculture } \\
\text { have increasingly complex functional units. The aim of the paper was } \\
\text { to analyse reliability of presently produced farm tractors. Three tractor } \\
\text { makes were evaluated and the analysis of failures was carried out with } \\
\text { regard to functional units. Based on the obtained results, the average } \\
\text { time of correct functioning and refreshment times and availability of } \\
\text { particular tractor makes were determined. It was stated that the obtained } \\
\text { empirical data of the correct functioning time and refreshment time may } \\
\text { be well described with exponential functions. Significant differences in } \\
\text { the values that determine the average time of correct functioning and } \\
\text { duration time of refreshment obtained by tractors of the investigated } \\
\text { makes were found. From among particular functional units, electric and } \\
\text { hydraulic systems were the most often damaged, regardless the tractor } \\
\text { make. }\end{array}$} \\
\hline $\begin{array}{l}\text { Key words: } \\
\text { reliability, } \\
\text { farm tractor, } \\
\text { failures, } \\
\text { refreshment time }\end{array}$ & \\
\hline
\end{tabular}

\section{Introduction}

A structure of modern farm tractors is increasingly advanced. The changes concern mainly functional solutions (Francik, 2009). It results from higher requirements of clients related to the work comfort and its bigger performance. Moreover, stricter norms for pollution generated by diesel engines are introduced. Thus, systems that limit emission of hazardous substances are used. Moreover, elements of electronics and informatics for control of tractor systems are introduced. Modern wheeled tractors use mechatronic technologies for control of operation of specific sub-assemblies, inter alia, engine, drive system, functional sub-assemblies of a unit and working elements of a machine (Cieślikowski and Pedryc, 2009). The use of electronic systems that manage the operation of particular sub-assemblies, except for facilitation and improvement of the control quality caused an increased level of the complexity of the structure of these sub-assemblies. Therefore, additionally introduction 
of electronic systems used for on-board diagnostics of these vehicles has become necessary (Mamala et al., 2008). Majority of the introduced functional solutions causes an increase of the complexity of the tractor structure which is exposed to a higher number of damages (Gromadko et al., 2008).

Farm tractors due to the nature of work are exposed to a high risk of damages. It results from complex working processes during their exploitation which take place in difficult and thus variable environmental conditions. Depending on the needs, tractors may be used both for various types of field works and for transport on public roads. In the mentioned conditions, damages occur and the processes of wear and tear with a varied nature (Bieniek, 2013). This enables completion of works or causes extensive deterioration of the efficiency of work, increase of fuel consumption of exhaust fumes emission. Results of such failures influence the working process (Merkisz et al., 2013). In case of farm tractors due to the realisation of seasonal tasks (ploughing, sowing, harvesting etc.), maintaining them in the continuous utility is especially important. Fast detection of damages enables obtaining considerable availability, reduces repair costs, and time of possible stoppages. The issue of assessment of farm tractors reliability is considerably rarely presented in the scientific literature. In the paper by Durczak et al., (2018) results of the research on reliability of tractors Zetor with the power of 45-90 kW was analysed. Reliability was described with the exponential function and the average time of correct functioning was $271 \mathrm{mth}$. Also, in the paper by Poozesh et al, (2012) reliability of MF tractors was described with the exponential function and the time of correct functioning was only $40 \mathrm{~h}$.

The objective of the paper was to analyse failures and assess the reliability of presently produced farm tractors in the conditions of the Polish agriculture.

\section{Research method}

According to the commonly used definition, reliability of a tractor is its reliability, measured with an ability to maintain significant properties within admissible limits in the set conditions and time (PN-EN 60300-1:2015-01). The reliability theory has quite well-developed mathematical bases which constitute a starting point for any numerical analyses of shaping the reliability in varied external and internal functions (Gertsbakh, 2005). The basis of decision taken in the process of production and exploitation is a synthesis of analysis of results from the reliability test of tractors in traditional, for this group, external functions. Analysis of reliability concerns all stages of the existence of the facility; the biggest amount of information is obtained during the studies performed in real conditions of exploitation (Mikołajczak and Napiórkowski, 2016; Napiórkowski and Szczyglak, 2015).

The physics of failures is a basic issue considered in reliability modelling. It consists in knowledge and understanding of a widely understood destructive processes that influence the technical condition of a machine. The physics of damages is a starting issue for the use of algorithms that describe degradation of the investigated elements under the external impact of chemical, mechanical, thermal, or electric factors.

A tractor failure takes place under the influence of the energy carried by it. Depending on the type of energy that prevails in given conditions, the reasons of failures to elements may be divided into the following groups: 
- A failure from step stimuli (sudden) that occur as a result of step stimuli the values of which exceeded the set admissible values.

- Failures from cumulative stimuli (natural), which result from irreversible changes of initial properties of the facility that take place during exploitation.

- Failures from relaxative stimuli which result from direct impact of cumulative and step stimuli,

- Failures due to non-related reasons, failures occur as a result of overlapping of several reasons at the same time.

The following distribution of a random variable was used for estimation of reliability indices:

- exponential distribution - characterizes with a feature "lack of memory", failures occur as a result of the impact of random external factors (Fig.1).

- Weibull's distribution - describes failures that occur as a result of overlapping of the failure reason, i.e. simultaneous wear of material gradual and sudden (Fig. 2).

- Normal distribution, logarithmic normal distribution - reflect natural ageing processes which result from cumulative activity of stress in the elements of objects, in the second case - they are caused by fatigue wear and tear (Fig.3).

Characteristics of reliability were referred to particular investigated tractor makes, and they concerned:

- Reliability function $-\mathrm{R}(\mathrm{t})=\mathrm{P}(\mathrm{T} \geq \mathrm{t})$, where $\mathrm{T}$ - realization of random variable of the correct functioning time, $\mathrm{t}-$ time, $\mathrm{P}-$ probability.

- Distribution function $-\mathrm{F}(\mathrm{t})=\mathrm{P}(\mathrm{T} \leq \mathrm{t})$.

- Refreshment time $-\mathrm{G}(\mathrm{t})=\mathrm{P}(\mathrm{To} \leq \mathrm{t})$, where $\mathrm{T}_{\mathrm{o}}$ - realization of random variable of the refreshment time.

- Mean Time Between Failures $-\mathrm{MTBF}=\mathrm{E}[\mathrm{R}(\mathrm{t})]$.

- Mean Time to Repair - MTTR = E [G(t)].

- Availability $-\mathrm{A}=\mathrm{MTBF} / \mathrm{MTBF}+\mathrm{MTTR})$.

$-\lambda(\mathrm{t})-$ damage intensity function.

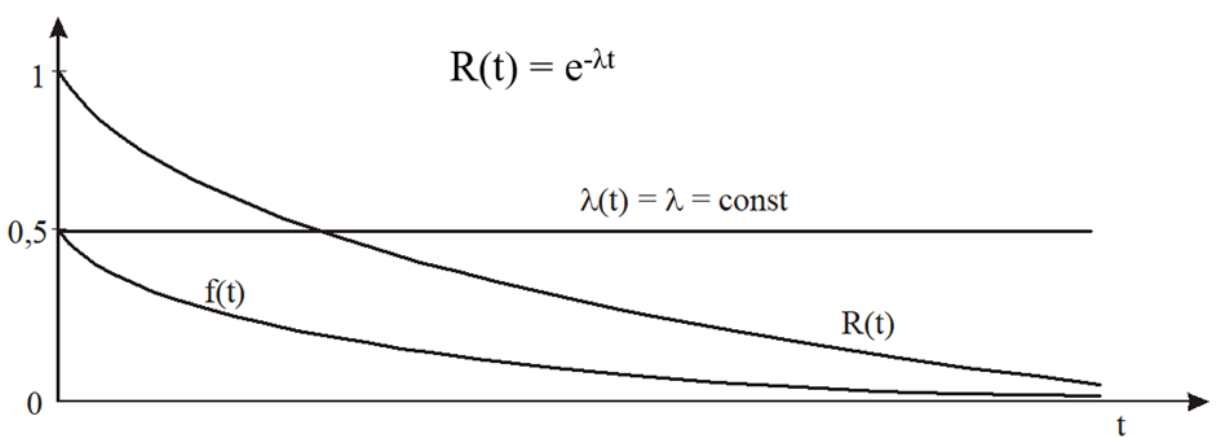

Figure 1. Characteristic of functions describing exponential distribution, $f(t)$ - probability density function 


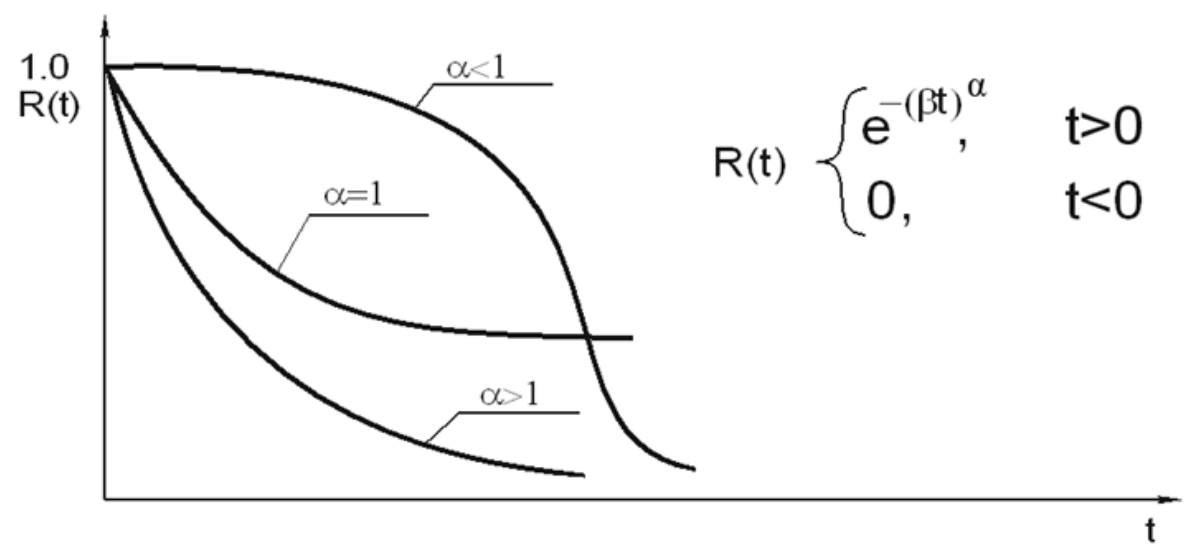

Figure 2. Reliability function of Weibull's distribution, $\alpha$ - shape parameter, $\beta$-scale parameter

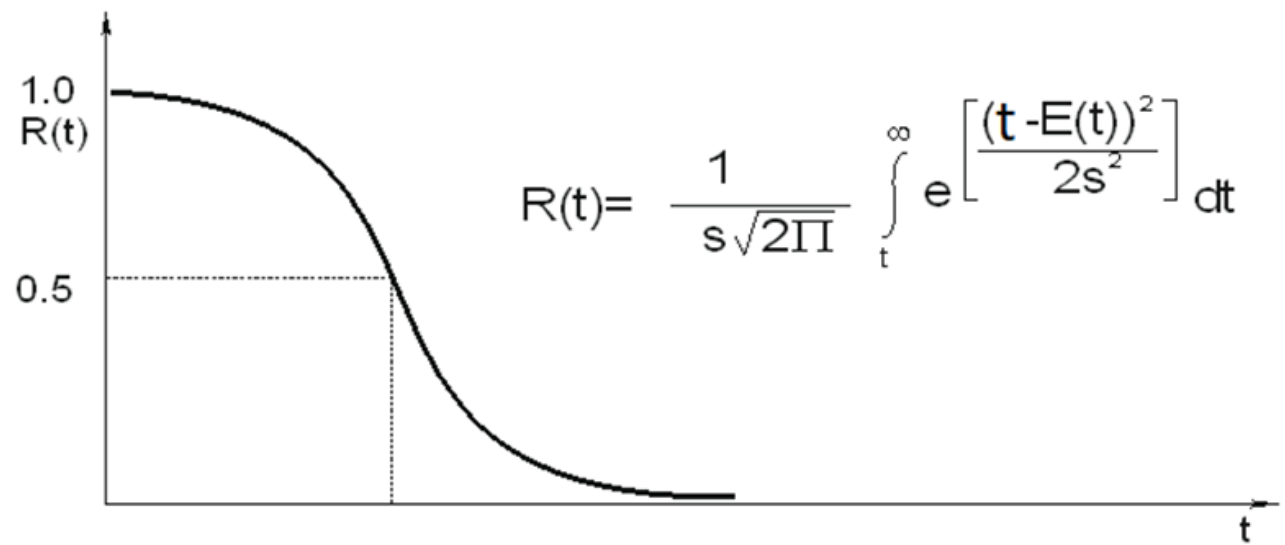

Figure 3. Reliability function of normal distribution $-s-$ standard deviation, E-expected value

The object of studies in the paper were farm tractors of three producers. They were marked in the paper as A, B, C. In total failures in 90 tractors were analysed, 30 in each of the selected makes. Table 1 presents a list of basic information on the investigated farm tractors. New tractors were tested for a varied time i.e. from two to nine years of operation. These vehicles were working from 346 to 9200 hours. They had power from ca. $80 \mathrm{KM}$ to ca. 205 KM. Tractors were subjected to observation in real conditions without interference in the operation course. They were used in all types of works carried out in farms. During the studies, the usage time, refreshment time including time of waiting for repair and its realization, type of the damaged unit and the reason for damage were recorded. Tractors were divided into the following units: engine along with equipment, gear box, drive transmission unit, electrical and drive system. 
Analysis of failures...

Table 1.

List of investigated tractors of A manufacturer

\begin{tabular}{cccc}
\hline Manufacturer: & Production years & $\begin{array}{c}\text { Number } \\
\text { of operation years }\end{array}$ & $\begin{array}{c}\text { Range } \\
\text { of worked hours (h) }\end{array}$ \\
\hline A & $2009-2016$ & $2-9$ & $900-9000$ \\
B & $2009-2014$ & $4-9$ & $346-9200$ \\
C & $2009-2016$ & d 2 do 9 & $500-9000$ \\
\hline
\end{tabular}

Assessment of compliance of theoretical models of reliability referred to the empirical data was performed with test $\lambda$ - Kolmogorov-Smirnov at the level of significance $\alpha=0.5$

\section{Results of research}

In total, 111 failures were registered in tractors by manufacturer A, 76 in tractors by manufacturer B and 73 failures in vehicles by manufacturer C. It constituted respectively 3.7 failures per one tractor, 2.53 and 2.43. The list of failures in particular units was presented in table 3 . In case of tractors by A make, a considerably higher number of failures to an engine (16 failures) than in case of two remaining producers was reported (Fig.4). An analogous situation occurred in case of a clutch. 13 failures of this element in tractors A were reported , 8 in tractors $\mathrm{C}$ and only 5 in tractors $\mathrm{B}$. Whereas in case of the gearbox considerably more failures occurred in C producer's tractors (4) than in the remaining makes. Tractors by $\mathrm{C}$ and $\mathrm{B}$ manufacturers had a permanent transmission system of a drive where respectively 3 and 6 failures were reported. On the other hand, in tractors A there were as much as 16 failures. In tractors of all producers, a particularly substantial number of failures was determined in the hydraulic system and in the electric system. The higher number of failures in the hydraulic system occurred in tractors A (33), then in tractors C (26) and the least in B producer's tractors (23). Also, a high number of failures was determined in the electric system of all tractors. These failures concern mainly a starter and alternator. The highest number of failures to these elements occurred in B producer's tractors. Failures of an alternator were reported in 18 cases and a starter in 17. In tractors of A producer, 15 failures of alternators and 16 of starters were reported. The least number of failures was reported in the $\mathrm{C}$ producer's tractors. These were 10 failures of an alternator and 14 failures of a starter. 
Table 2.

List of the number of failures in the investigated tractors

\begin{tabular}{|c|c|c|c|}
\hline & & \multicolumn{2}{|c|}{ Number of failures in time interval $(0 ; t)$} \\
\hline Sub-assembly & Manufacturer A & Manufacturer B & Manufacturer C \\
\hline Number of worked hours $t$ & 9000 & 9000 & 9000 \\
\hline \multicolumn{4}{|c|}{ Engine } \\
\hline Piston-crank system & 0 & 0 & 1 \\
\hline Fuel system & 9 & 5 & 3 \\
\hline Cooling system & 2 & 1 & 0 \\
\hline Engine smearing system & 0 & 0 & Turbo compressor \\
\hline Turbo compressor & 5 & 1 & 2 \\
\hline \multicolumn{4}{|c|}{ Gear box } \\
\hline Clutch & 13 & 5 & 8 \\
\hline Gearbox bed & 0 & 0 & 2 \\
\hline Gearbox transmission & Turbo compressor & 0 & 2 \\
\hline \multicolumn{4}{|c|}{ Drive transmission system } \\
\hline Front axle & 5 & 2 & 2 \\
\hline Back axle & 3 & Turbo compressor & 0 \\
\hline Power take-off & 8 & 3 & Turbo compressor \\
\hline \multicolumn{4}{|c|}{ Hydraulic pump } \\
\hline Hydraulic pump & 8 & Turbo compressor & 0 \\
\hline External hydraulics & 13 & 9 & 9 \\
\hline TUZ & 12 & 13 & 17 \\
\hline \multicolumn{4}{|c|}{ Electric system } \\
\hline On-board computer & Turbo compressor & 0 & 0 \\
\hline Alternator & 15 & 18 & 10 \\
\hline Starter & 16 & 17 & 14 \\
\hline
\end{tabular}

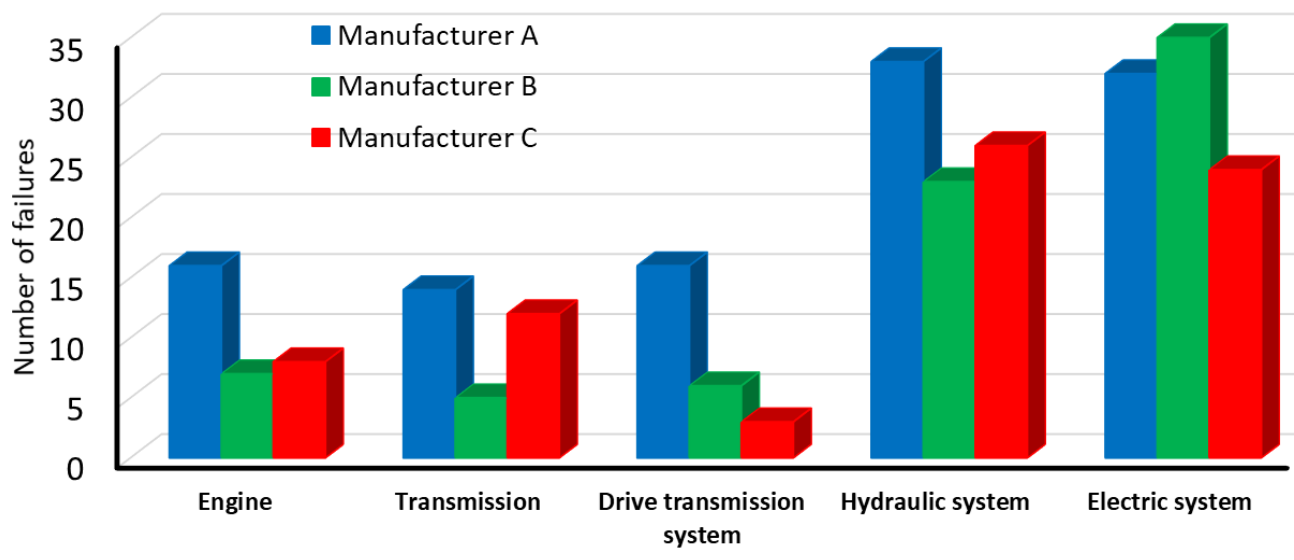

Figure 4. List of unit failures 
Analysis of failures...

From among the presented reliability models for the time of correct functioning, the best adjustment was in case of the exponential distribution at the significance level $\alpha=0.5$ in all investigated tractors (Fig. 5-7) Tractor failures resulted from the reasons that are not applicable to their technical condition (Grabski and Jaźwiński, 2009). The exponential distribution is a distribution that expresses the most random process. It is characterised, among others, with the inability to predict failures. Also, in case of the refreshment time, the function that best describes is the exponential function (Fig. 5-7).

Figure 8 lists the courses of the reliability function, which characterised tractors in all three manufacturers. Based on these data, one may conclude that the biggest reliability was in case of B manufacturer's tractors, while the lowest in case of A manufacturer's tractors.

While, figure 9 presents a list of function of tractor refreshment time. C manufacturer's tractors have the shortest refreshment time. The time included time of failure identification, time related to obtaining spare parts and relevant repair.
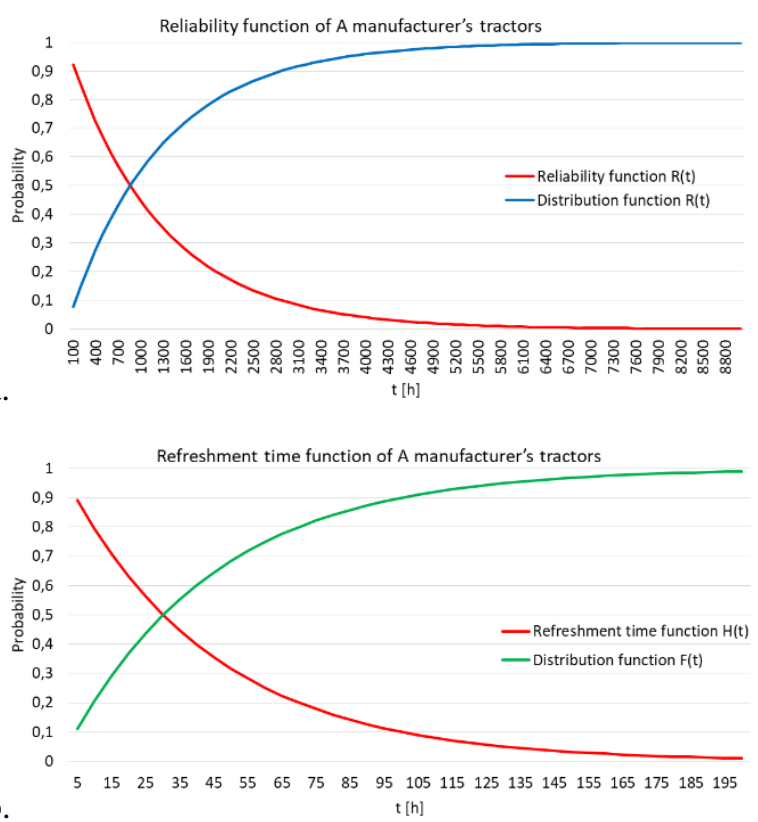

Figure 5 Manufacturer A: a. Tractor reliability function; $b$. Refreshment time function 
Jerzy Napiórkowski, Jarosław Gonera
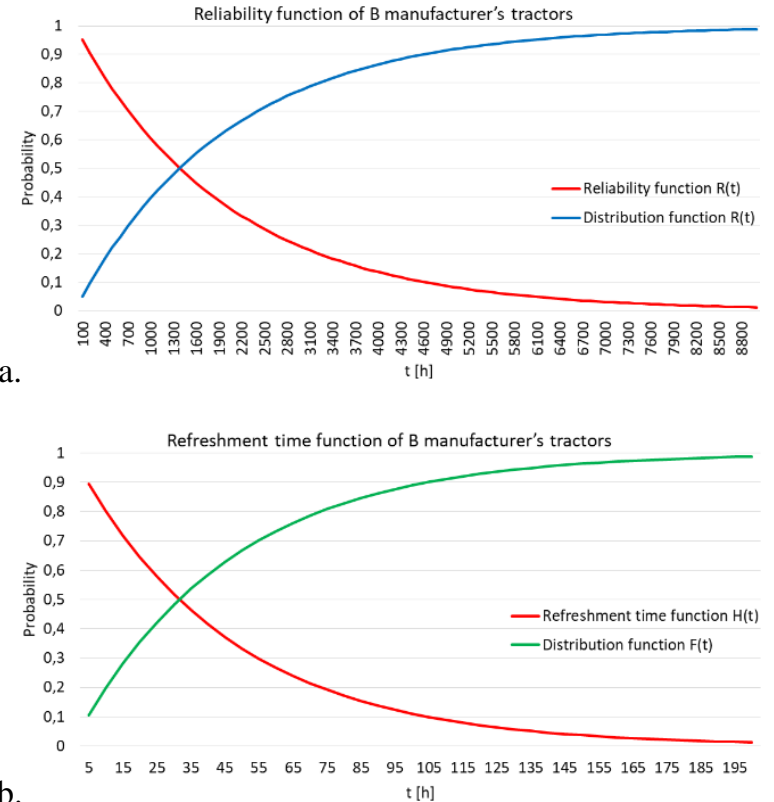

Figure 6. Manufacturer B: a Tractor reliability function; $b$. Refreshment time function

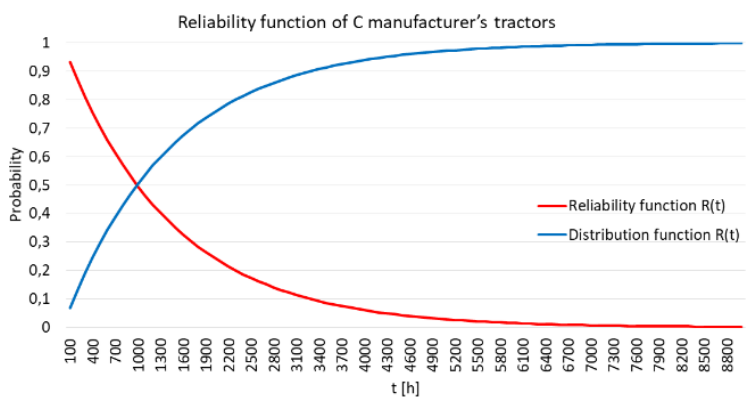

a.

b.

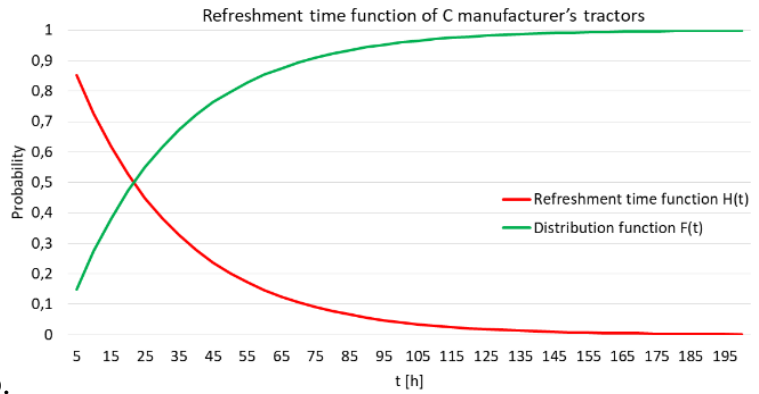

Figure 7. Manufacturer $C$ : a Tractor reliability function; $b$. Refreshment time function 96 


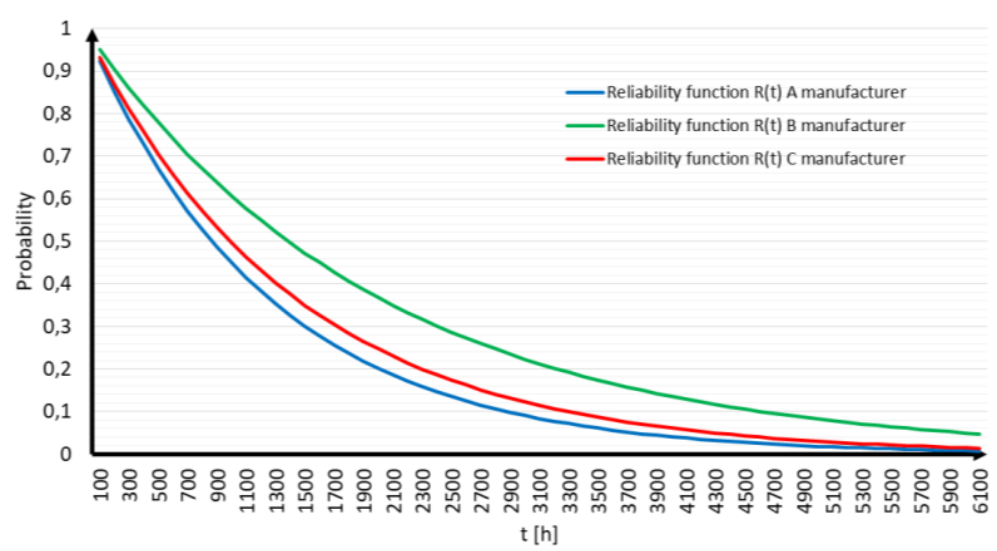

Figure 8. Farm tractors reliability function

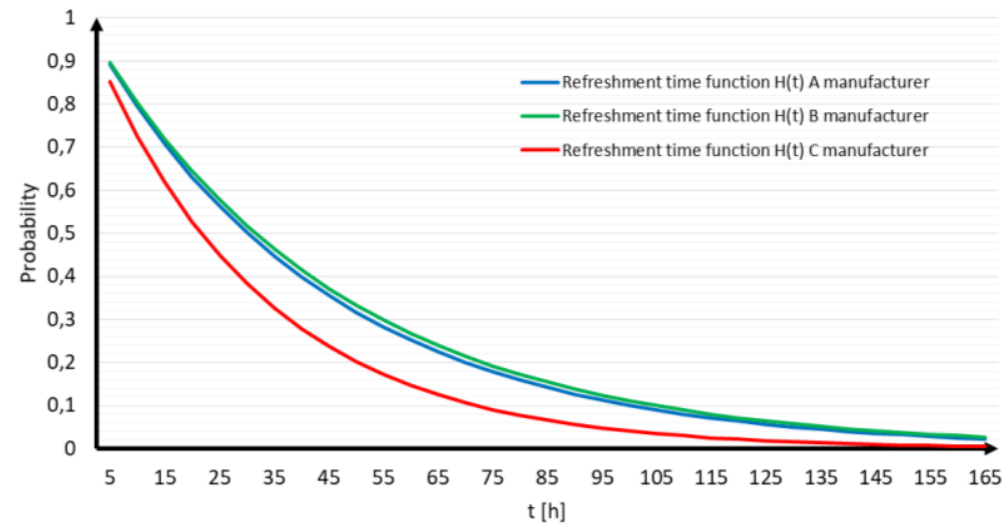

Figure 9. Functions of refreshment time of farm tractors

Numerical characteristics of the reliabilities was presented in table 3. B manufacturer's tractors had the highest average refreshment time, which was over $46 \mathrm{~h}$. A slightly shorter average time of refreshment was in make A vehicles (over $43 \mathrm{~h}$ ). A considerably shorter average time of refreshment was in C manufacturer's tractors (over $31 \mathrm{~h}$ ). A considerably shorter time of refreshment may prove that the time of removal of failures reported in those tractors was the shortest. The obtained function forms that describe reliability are concurrent with functions presented in Durczak's (2018) and Poozesh 's (2012) papers. The differences concern mainly the intensity of failures and the correct functioning time. Presently, the produced tractors have over four-time better reliability indexes. 
Jerzy Napiórkowski, Jarosław Gonera

For all tractors, which were investigated in the paper, a statistical analysis was performed, which aimed at assessment whether between different manufacturers' tractors there are significant differences of the correct functioning time (fig. 10) and the average refreshment time (Fig.11).

Table 3 .

Characteristics of reliability of the investigated farm tractors

\begin{tabular}{lccc}
\hline Parameter & $\begin{array}{c}\text { Manufacturer } \\
\text { A }\end{array}$ & $\begin{array}{c}\text { Manufacturer } \\
\text { B }\end{array}$ & $\begin{array}{c}\text { Manufacturer } \\
\text { C }\end{array}$ \\
\hline Number of failures & 111 & 76 & 73 \\
Number of failures per a tractor & 3.70 & 2.53 & 2.43 \\
$\mathrm{U}_{\mathrm{c}}$ & 1252.21 & 1944.74 & 1468.49 \\
Average time of correct functioning MTBF (h) & 43.27 & 46.51 & 31.27 \\
Average refreshment time MTTR (h) & 0.967 & 0.976 & 0.979 \\
Availability A & $\mathrm{e}^{-0.0008 t}$ & $\mathrm{e}^{-0.0005 t}$ & $\mathrm{e}^{-0.0007 t}$ \\
Reliability model R (t) & $\mathrm{e}^{-0.023 \mathrm{t}}$ & $\mathrm{e}^{-0.022 \mathrm{t}}$ & $\mathrm{e}^{-0.032 \mathrm{t}}$ \\
Renewal time model G(t) & & &
\end{tabular}

A zero hypothesis on the absence of differences between the average time of correct functioning in comparison to an alternative hypothesis on occurrence of significant differences in the average time of correct functioning was assumed. The analysis was performed at the level of significance $\alpha=0.05$ Based on the set data it was reported that there were no statistically significant differences between the investigated times. It resulted from a considerable distribution of the values of the correct functioning time in particular tractor makes. This relation confirms the assumptions of the assumed reliability model which describes the most failures with a high random character of occurrence.

The same procedure was carried out in case of the average duration of refreshment. The analysis was performed at the level of significance $\alpha=0.05$ It was concluded that there were no significant differences on account of statistics between the length of the refreshment time of tractors manufactured by particular manufacturers. No statistical differences resulted from a big distribution between the renewal duration of particular tractors of one manufacturer. In case of each tractor make, both these failures were identified which were quite fast removed as well as those the removal of which required a considerably higher time input. 
Analysis of failures...

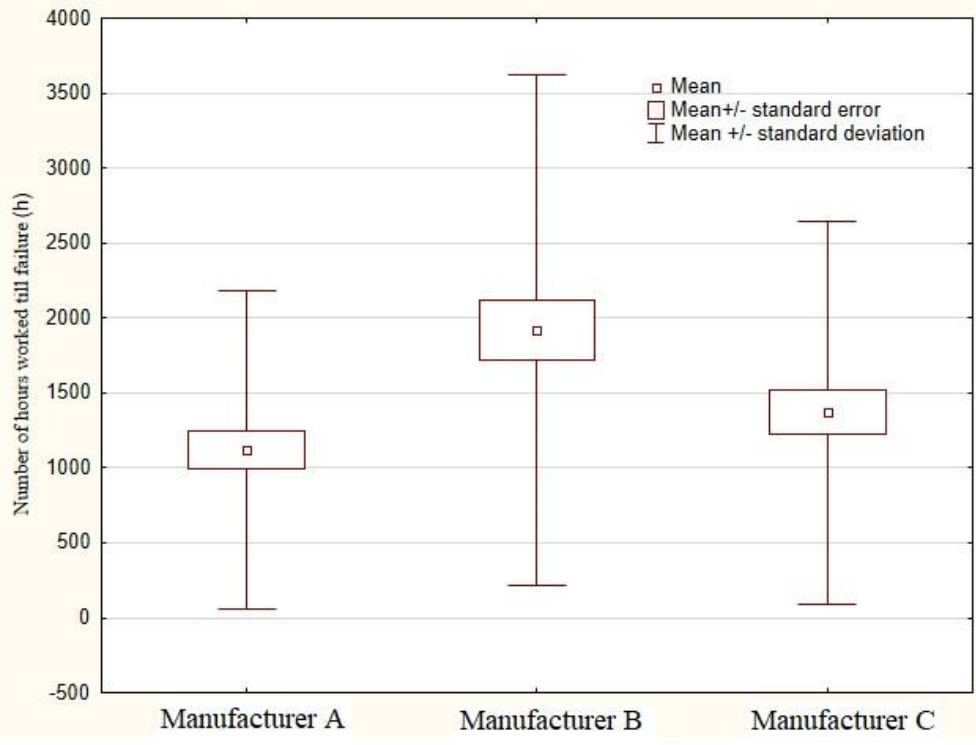

Figure 10. Statistical analysis for the number of hours worked to a failure in tractors by manufacturers $A, B$ and $C$

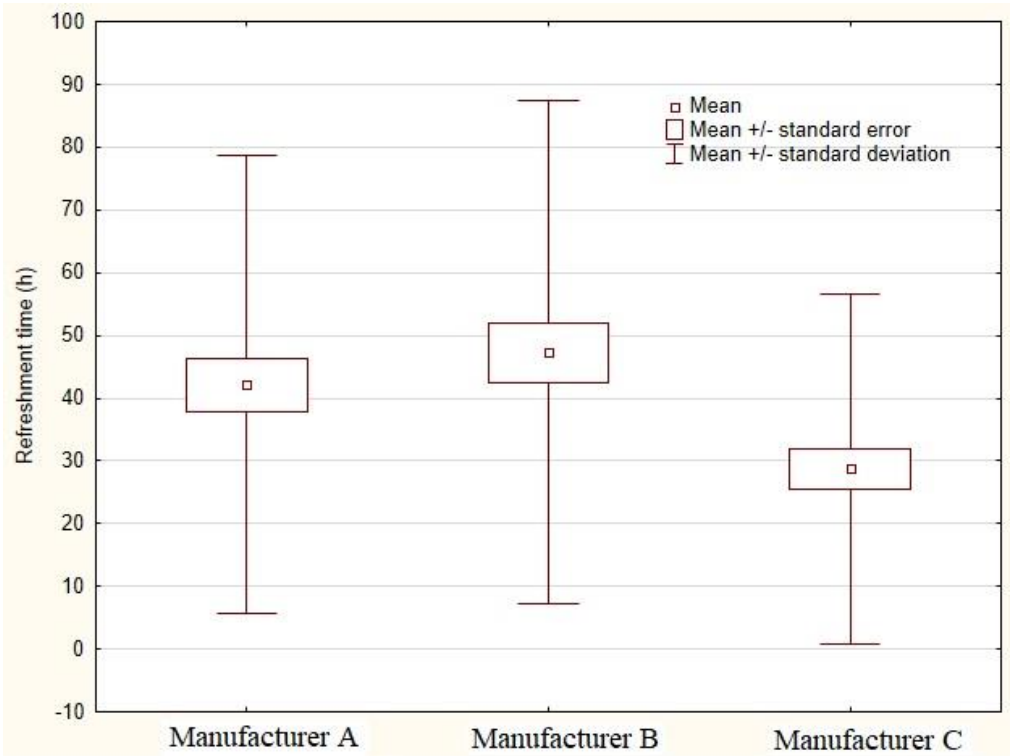

Figure 11. Statistical analysis for the refreshment time of $A, B$ and $C$ manufacturers' tractors. 


\section{Conclusions}

Based on the results obtained in the paper, the following conclusions can be made:

1. Significant differences in values that determine the average time of correct functioning and duration of renewal obtained by tractors of the investigated makes were found.

2. The average time of correct functioning in case of a tractor by manufacturer B was as much as $50 \%$ longer than the tractor by manufacturer $\mathrm{A}$ and $30 \%$ longer than the tractor by manufacturer $\mathrm{C}$. While for this make, the longest time of refreshment was obtained, and it was longer by $7 \%$ in case of a tractor make A and $38 \%$ of make C. For the obtained numerical values no statistical differences were reported. It resulted from the fact that in the investigated tractor makes, a noticeably big distribution of the values of the investigates times were determined.

3. Failures to tractors occurred in random moments, regardless a technical condition of a tractor and resulted the most often from the environmental enforcements e.g. improper fuel (17 damages).

4. Very long times of refreshment that were reported, resulted mainly from the time of waiting for spare parts and resulted from the strategies of supply carried out by particular repair services.

5. The obtained empirical data well describe the exponential reliability law as well as the exponential renewal law. These models are commonly used for complex machines which include electronic solutions, in which occurrence of failures does not result from the process of natural ageing.

\section{References}

Bieniek, A. (2013). Wewnatrzsilnikowe ograniczenie emisji substancji szkodliwych w silniku wyposażonym w układ EGR pojazdu pozadrogowego. Agricultural Engineering, 2(143), 31-41.

Cieślikowski, B., Pedryc, N. (2009). Koncepcja nadzoru nad maszynami przez komputer pokładowy ciągnika w czasie rzeczywistym z wykorzystaniem magistrali informatycznej LIN. Agricultural Engineering, 9(118), 29-34 .

Durczak, K., Ekielski, A., Żelaziński, T. (2018). Calculation of the reliability function from actual failures resulting from the operation of one make of farm tractors. Journal of Research and Applications in Agricultural Engineering, 63(1), 18-22.

Francik, S. (2009). Metoda oceny nowoczesności techniczno-konstrukcyjnej ciągników rolniczych wykorzystująca sztuczne sieci neuronowe cz. I: założenia metody. Agricultural Engineering, 9(143), 41-47.

Gertsbakh, J. (2005). Reliability Theory With Applications to Preventive Maintenance. Springer Berlin Heidelberg New York.

Grabski, F., Jażwiński, J. (2009). Funkcje o losowych argumentach w zagadnieniach niezawodności, bezpieczeństwa i logistyki. Wydawnictwa Komunikacji i Łączności, Warszawa.

Gromadko, J., Hong, V., Miler, P. (2008). Applications of NRTC Cycle to determine a different fuel consumption and harmful emissions caused by changes of engines technical conditions. Maintenance and Reliability, 4, 63-65.

Mamala, J., Jantos, J., Augustynowicz, A. (2009). Diagnostyka predykcyjna ciągników rolniczych. Agricultural Engineering, 5(118), 97-101.

Merkisz, J., Lijewski, P., Fuć, P., Weymann, S. (2013). Exhaust emission tests from non-road vehicles conducted with the use of PEMS analyzers. Eksploatacja i Niezawodność - Maintenance and Reliability, 15(4), 364-368. 
Analysis of failures...

Mikołajczak, P., Napiórkowski, J. (2016). Analysing the Reliability of Working Parts Operating in Abrasive Soil Pulp Taking Into Consideration Confounding Factors. Maintenance and Reliability, 18(4), 544-551.

Napiórkowski, J., Szczyglak, P, Kołakowski, K. (2015). Telematics used in the campaigns machinery safety management systems. In: Nowakowski et al. (eds.) Safety and Reliability: Safety and Reliability: Methodology and Applications -Proceedings of the European Safety and Reliability Conference, ESREL 2014 Location: Wroclaw, POLAND Date: SEP 14-18, 2014 Taylor \& Francis Group, London, 1833-1839.

PN-EN 60300-1:2015-01. Zarządzanie niezawodnością - Część 1: Wytyczne dotyczące zarządzania i zastosowania.

Poozesh, M., Mohtasebi, S.S., Ahmadi, H., Asakereh, A. (2012). Determining the reliability function of farm tractors. Elixir Project Management, 47, 9074-9078.

\section{ANALIZA USZKODZEŃ I MODELE NIEZAWODNOŚCI CIĄGNIKÓW ROLNICZYCH}

Streszczenie. Ciągniki rolnicze ze względu na charakter pracy narażone są na duże ryzyko wystąpienia uszkodzeń. Zagadnienie ich niezawodności jest niezwykle istotne w aspekcie terminowości realizacji prac rolniczych w sezonach agrotechnicznych. Współcześnie dostarczane do rolnictwa ciągniki charakteryzują się coraz większą złożonością zespołów funkcjonalnych. Celem pracy była analiza niezawodności obecnie produkowanych ciągników rolniczych. Ocenie poddano 3 marki ciągników, zaś analizę uszkodzeń przeprowadzono na poziomie zespołów funkcjonalnych. Na podstawie uzyskanych wyników wyznaczono średnie czasy poprawnego funkcjonowania i czasy odnowy oraz dyspozycyjność poszczególnych marek ciągników. Stwierdzono, że uzyskane dane empiryczne czasu poprawnego funkcjonowania oraz czasu odnowy mogą być dobrze opisane funkcjami wykładniczymi. Stwierdzono istotne różnice $\mathrm{w}$ wartościach określających średnie czasu poprawnego funkcjonowania oraz czasy trwania odnowy uzyskane przez ciągniki badanych marek. Spośród wyszczególnionych zespołów funkcjonalnych najczęstszym uszkodzeniom ulegały układy elektryczny i hydrauliczny, niezależnie od marki ciągnika.

Słowa kluczowe: niezawodność, ciągnik rolniczy, uszkodzenia, czas odnowy 